\title{
BAHAN AJAR BERBASIS SOSIOKULTURAL DAN KARAKTERISTIK DALAM MENGHADAPI MASYARAKAT EKONOMI ASEAN (MEA)
}

\author{
Oleh: Vera Yuli Erviana, S.Pd., M.Pd \\ PGSD FKIP Universitas Ahmad Dahlan \\ E-mail: vera.erviana@pgsd.uad.ac.id
}

\section{Ringkasan}

\begin{abstract}
Masalah penting yang sering dihadapi oleh guru dalam kegiatan pembelajaran adalah memilih atau menentukan bahan ajar atau materi pembelajaran yang tepat dalam rangka membantu siswa mencapai kompetensi. Hal ini disebabkan oleh kenyataan bahwa dalam kurikulum atau silabus, materi bahan ajar hanya dituliskan secara garis besar dalam bentuk materi pokok. Tugas guru adalah menjabarkan materi pokok tersebut sehingga menjadi bahan ajar yang lengkap. Sehingga diperlukan kecakapan dalam pembuatan bahan ajar khususnya dalam menghadapi era Masyarakat Ekonomi ASEAN (MEA), karena tenaga kependidikan sangat dibutuhkan dan harus berperan aktif dalam mensukseskan program ini. Pembuatan bahan ajar berbasis sosiokultural merupakan salah satu langkah awal para guru dalam menyampaikan materi kepada siswa sekolah dasar.
\end{abstract}

Kata kunci: Bahan ajar, sosiokultural, MEA, guru, kurikulum.

\begin{abstract}
An important problem that teachers often encounter in learning activities is choosing or determining the right teaching materials or learning materials in order to help students achieve competence. This is due to the fact that in the curriculum or syllabus, teaching material material is only outlined in the form of the subject matter. Teacher's job is to describe the subject matter so that it becomes a complete teaching material. Therefore, skills are needed in making teaching materials, especially in facing the era of ASEAN Economic Community (MEA), because the educational staff is needed and must play an active role in the success of this program. Making sociocultural-based teaching materials is one of the first steps teachers in delivering the material to elementary school students.
\end{abstract}

Keywords: teaching materials, sociocultural, MEA, teachers, curriculum.

\section{A. PENDAHULUAN}

\section{Latar Belakang}

Bahan ajar atau materi ajar adalah bahan atau materi yang harus dipelajari siswa dalam satu keatuan waktu tertentu. Bahan ini dapat berupa konsep, teori, dan rumus-rumus keilmuan; cara, tatacara, dan langkah-langkah untuk mengerjakan sesuatu; dan normanorma, kaidah-kaidah, atau nilai-nilai. Bahan ajar untuk pembelajaran koginitif (pengetahuan) akan berwujud teori-teori atau konsep-konsep keilmuan. Bahan ajar untuk pembelajaran psikomotorik (keterampilan) akan berwujud cara atau prosedur mengerjakan dan menyelesaikan sesuatu. Sedangkan bahan ajar untuk pembelajaran afektif (sikap) akan 
berwujud nilai-nilai atau norma-norma. Jadi, sebagai calon pendidik nantinya guru harus mampu memilih bahan ajar menyangkut dengan aspek yang dipelajari siswa harus memenuhi ranah koginitif, psikomotorik, dan afektif. Guru dalam menjalankan proses pembelajaran dibutuhkan suatu bahan ajar karena digunakan untuk membantu guru dalam kegiatan belajar mengajar di kelas. Dan dari proses belajar mengajar ini akan diperoleh suatu hasil yang pada umumnya disebut hasil pengajaran.

\section{Profil Wilayah}

Program pengabdian masyarakat diperuntukan bagi sekolah-sekolah dasar Muhammadiyah Se-Kecamatan Seyegan yang dilaksanakan di SD Muhammadiyah Gendol 7. Sekolah ini merupakan mitra bagi Universitas Ahmad Dahlan Yogyakarta karena pernah dijadikan lokasi pelaksanaan program magang dasar mahasiswa Prodi PGSD semester 2 tahun lalu. Sekolah ini beralamatkan di Klangkapan, Kelurahan Margoluwih, Kecamatan Seyegan, Sleman, Daerah Istimewa Yogyakarta, Kode Pos 55561.

\section{B. METODE PELAKSANAAN}

Metode program pengabdian masyarakat dengan mengadakan pelatihan pembuatan bahan ajar berbasis sosiokultural dengan mempraktikannya langsung di bawah pengawasan dan pendampingan.

\section{Metode ceramah dan diskusi}

Metode ini digunakan untuk memberikan pemahaman konsep berbasis sosiokultural melalui media keterampilan seni dalam mengembangkan bahan ajar guru-guru sekolah dasar.

\section{Praktek dan diskusi}

Metode praktek akan memberikan pengalaman konkret tentang bagaimana menggali ide, gagasan berbasis sosiokultural serta mengaktualisasikanya ke dalam karya keterampilan melalui praktek kelompok (joint construction).

\section{Self and Group Reflection}

Metode ini dipakai untuk menguatkan pemahaman/ pengetahuan dan praktek tentang bagaimana menggali ide, gagasan berbasis sosiokultural kemudian mengaktualisasikanya ke dalam karya keterampilan melalui refleksi kelompok serta mengambil kemanfatan workshop baik terhadap pribadi guru maupun kemanfatan terhadap siswa dan institusi sekolah.

\section{LANDASAN TEORI}

\section{Pengertian Bahan Ajar}

Bahan ajar merupakan informasi, alat, dan teks yang diperlukan guru untuk perencanaan dan penelaahan implementasi pembelajaran. Menurut para ahli pengertian bahan ajar adalah sebagai berikut:

a. Menurut National Center For Competency Based Training (2007), bahan ajar adalah segala bentuk bahan yang digunakan untuk membantu guru atau instuktur 
dalam melaksanakan proses pembelajaran dikelas.Bahan yang dimaksud bisa berupa tertulis maupun tak tertulis.

b. Menurut Pails Ache dalam Diknas, bahan ajar adalah gabungan dari dua kata "teaching material". Maknanya terdiri atas teaching yang berati mengajar dan material yang berarti bahan. Jadi bahan ajar merupakan seperangkat materi pembelajaran yang disusun secara sistematis, menampilkan sosok utuh dari kompetensi yang akan dikuasai peserta didik dalam kegiatan pembelajaran.

c. Menurut Suharsimi Arikunto dalam Belawati dkk, memberikan pendapat tentang pentingnya bahan ajar yakni bahan ajar merupakan inti yang ada dalam kegiatan pembelajaran, karena memang bahan pembelajaran itulah yang diupayakan untuk dikuasai pembelajar.

Dari beberapa pandangan mengenai pengertian bahan ajar tersebut dapat dipahami bahwa bahan ajar merupakan segala bahan (baik informasi,alat maupun teks) yang disusun secara sistematis yang menampilkan sosok utuh dari kompetensi yang akan dikuasai oleh peserta didik yang digunakan dalam proses pembelajar dengan tujuan perencanaan dan penelaahan implementasi pembelajaran. Misalnya, buku pelajaran, modul, atau make, bahan ajar audio, bahan ajar interaktif, dan sebagainya.

\section{Jenis-Jenis Bahan Ajar}

\section{a. Bahan cetak}

1) Handout, adalah bahan tertulis yang disiapkan oleh masing-masing guru untuk memperkaya pengetahuan peserta didik. Handout biasanya dambil dari beberapa literatur yang memiliki relevansi dengan materi yang diajarkan.

2) Buku, adalah bahan tertulis yang menyajikan ilmu pengetahuan.

3) Modul, adalah sebuah buku yang ditulis dengan tujuan agar peserta didik dapat belajar secara mandiri tanapa atau dengan bimbingan guru, sehingga paling tidak modul berisi komponen dasar bahan ajar.

4) Lembar kerja siswa, adalah lembaran yang berisikan tugas yang harus dikerjakan oleh peserta didik. Lembar kegiatan biasanya berupa petunjuk, langkah-langkah untuk menyelesaikan suatu tugas.

5) Foto/gambar, memiliki makna yang lebih baik dibandingkan dengan tulisan, sebagai bahan ajar tentu saja diperlukan satu rancangan yang baik agar setelah selesai melihat sebuah atau serangkaian foto/gambar siswa dapat melakukan sesuatu yang pada akhirnya satu atau lebih kompetensi dasar.

\section{b. Bahan ajar dengar (audio)}

1) Kaset, sebuah kaset yang direncanakan sedemikian rupa, sehingga menjadi sebuah program yang dapat digunakan sebagai bahan ajar. Media kaset dapat menyimpan suara yang dapat secara berulang-ulang diperdengarkan kepada peserta didik yang menggunakannya sebagai bahan ajar. Bahan ajar jenis ini biasanya digunakan untuk pembelajaran bahasa atau musik. 
2) Radio broadcasting, adalah media dengar yang dapat dimanfaatkan sebagai bahan ajar, dengan radio peserta didik bisa belajar sesuatu. Radio juga dapat dimanfaatkan sebagai sumber belajar. Program radio dapat dirancang sebagai bahan ajar, misalnya pada jam tertentu guru merencanakan sebuah program pembelajaran melalui radio dengan mendengarkan berita siaran langsung suatu kejadian/ fakta yang sedang berlangsung.

\section{c. Bahan ajar pandang}

Video/ film, program video telah dibuat dalam rancangan lengkap, sehingga setiap akhir dari dari penayangan video siswa dapat menguasai satu atau lebih kompetensi dasar. Dengan video/ film seseorang dapat belajar dengan sendiri.

\section{Karakteristik Bahan Ajar}

Pembelajaran mempunyai karakteristik yang sangat berbeda. Hal ini disebabkan karena pembelajaran mempunyai karakteristik yang sangat berbeda. Hal ini disebabkan karena pembelajaran mempunyai karakteristik yang sangat berbeda. Secara institusional tujuan pembelajaran lebih ke arah pengembangan potensi dasar para siswa, karena potensi dasar ini sangat diperlukan untuk belajar dan pembelajaran ada tingkat pendidikan selanjutnya. Menurut Anonim (2009), bahan ajar harus memiliki beberapa karakteristik sebagai berikut:

1. Bahan ajar harus relevan dengan tujuan pembelajaran.

2. Bahan ajar harus sesuai dengan taraf perkembangan anak.

3. Bahan yang baik ialah bahan yang berguna bagi siswa baik sebagai perkembangan pengetahuannya dan keperluan bagi tugas kelak di lapangan.

4. Bahan itu harus menarik dan merangsang aktivitas siswa.

5. Bahan itu harus disusun secara sistematis, bertahap, dan berjenjang.

6. Bahan yang disampaikan kepada siswa harus menyeluruh, lengkap, dan utuh.

\section{Kriteria Pemilihan Bahan Pembelajaran}

1. Sesuai dengan tujuan pembelajaran: untuk mencapai tujuan instruksional khusus atau tujuan-tujuan tingkah laku. Karena itu, materi tersebut hendaknya sejalan dengan tujuan-tujuan yang telah dirumuskan.

2. Menjabarkan tujuan pembelajaran: setiap tujuan pembelajaran telah dirumuskan secara spesifik, dapat diamati dan terukur. Ini berarti terdapat keterkaitan yang erat antara spesifikasi tujuan dan spesifikasi bahan pembelajaran.

3. Relevan dengan kebutuhan peserta didik: bahan pembelajaran yang akan disajikan hendaknya sesuai dengan usaha untuk mengembangkan pribadi siswa secara bulat, dan utuh terkait dengan pengetahuan, keterampilan, serta nilai dan sikap.

4. Sesuai dengan kebutuhan masyarakat: bahan pembelajaran yang dipilih hendaknya turut membantu mereka memberikan pengalaman edukatif yang bermakna bagi perkembangan mereka menjadi manusia yang berguna dan mudah menyesuaikan diri dengan lingkungan dan masyarakatnya. 
5. Mempertimbangkan norma yang berlaku: pengetahuan dan keterampilan yang diperoleh dari bahan pembelajaran hendaknya dapat mengembangkan diri peserta didik sebagai manusia yang memiliki etika dan moral sesuai dengan sistem nilai dan norma-norma yang berlaku di masyarakat.

6. Tersusun dalam ruang lingkup dan urutan yang sistematik serta logis: bahan pembelajaran disusun secara berurutan dengan mempertimbangkan faktor perkembangan psikologis peserta didik. Dengan cara ini diharapkan isi bahan pembelajaran tersebut akan lebih mudah diserap oleh peserta didik dan tujuan pembelajaran dapat dapat tercapai.

7. Bersumber dari buku sumber yang baku, keahlian guru, masyarakat dan fenomena alam: Keempat faktor ini perlu diperhatikan dalam memilih bahan pembelajaran. Buku sumber yang baku dimaksud adalah yang disusun oleh para ahli dalam bidang pendidikan dan disusun berdasarkan GBPP yang berlaku. Meskipun belum tentu lengkap sebagaimana yang diharapkan, setidaknya keberadaan buku tersebut akan sangat membantu bagi penyusunan bahan pembelajaran. Keahlian guru dalam menyusun bahan pembelajaran tentu sangat penting, karena sumber utama dari proses belajar dan pembelajaran adalah guru itu sendiri. Guru dapat menyimak semua hal yang dianggapnya perlu untuk disajikan kepada peserta didik berdasarkan ukuran pribadianya. Masyarakat juga merupakan sumber yang luas, sedangkan fenomena alam merupakan sumber bahan pembelajaran yang paling besar.

\section{Bahan Ajar Berbasis Sosiokultural}

Sutarno (dalam Vera YuliErviana, 2014:25) menyatakan bahwa pemakaian budaya lokal (etnis) dalam pembuatan bahan ajar sangat bermanfaat bagi pemaknaan dan proses hasil belajar, karena peserta didik mendapatkan pengalaman langsung yang bersifat kontekstual dan bahan apersepsi untuk memahami konsep ilmu pengetahuan dalam budaya lokal (etnis). Dari pernyataan tersebut maka dapat kita cermati bahwa, dengan bahan ajar berbasis sosiokultural akan lebih bermakna dikarenakan hal-hal yang digunakan oleh guru bersifat kontekstual dengan nilainilai budaya sekitar.

Sutarno (dalam Vera Yuli Erviana, 2014:29) menyebutkan bahwa bahan ajar berbasis budaya dapat dibedakan menjadi empat macam, yaitu bahan ajar tentang budaya, bahan ajar dengan budaya, bahan ajar melalui budaya dan bahan ajar berbudaya. Berikut adalah penjelasan keempat macam hal yang telah disebutkan di atas:

1. Bahan ajar tentang budaya

Bahan ajar tentang budaya adalah menempatkan bahan ajar sebagai bidang ilmu. Budaya dipelajari dalam program studi khusus, tentang budaya dan untuk budaya. Dalam hal ini, budaya tidak terintegrasi dengan ilmu lain.

2. Belajar dengan budaya

Terjadi pada saat budaya diperkenalkan kepada siswa sebagai cara atau metode untuk mempelajarai pokok bahasan tertentu. Bahan ajar dengan budaya meliputi pemanfaatan beragam bentuk perwujudan budaya. Dalam bahan ajar 
dengan budaya, budaya dan perwujudan menjadi media pembelajaran dalam proses belajar, menjadi konteks penerapan prinsip atau prosedur dalam suatu mata pelajaran.

3. Bahan ajar melalui budaya

Merupakan strategi yang memberikan kesempatan kepada siswa untuk menunjukan pencapaian pemahaman atau makna yang diciptakannya dalam suatu mata pelajaran melalui ragam perwujudan budaya.

4. Bahan ajar berbudaya

Bahan ajar dengan budaya terjadi pada saat proses belajar-mengajar menggunakan simbol-simbol budaya setempat sebagai media pembelajaran, disamping sebagai media pembelajaran simbol-simbol budaya tersebut juga diperkenalkan kepada peserta didik sebagai kekayaan budaya setempat. Bahan ajar melalui budaya dimaknai sebagai perwujudan dari pemahaman peserta didik terhadap budaya lokal sekitar melalui karya-karya atau perwujudan budaya. Sedangkan bahan ajar berbudaya dimaksudkan dengan menanamkan nilai-nilai yang menjadi cirri khas budaya sekitar. Berikut adalah contoh pengintegrasian nilai-nilai sosiokultural dalam perangkat pembelajaran yang dikembangkan.

Tabel 1. Integrasi Nilai-nilai Sosiokultural

\begin{tabular}{|c|c|c|c|c|}
\hline No & Sub Tema & $\begin{array}{l}\text { Bahan ajar } \\
\text { dengan } \\
\text { Budaya (Media) }\end{array}$ & $\begin{array}{c}\text { Bahan ajar dengan } \\
\text { (Hasil Karya) }\end{array}$ & $\begin{array}{l}\text { Bahan ajar dengan } \\
\text { Berbudaya (RPP) }\end{array}$ \\
\hline 1. & $\begin{array}{l}\text { Pengalaman } \\
\text { Bersama Teman }\end{array}$ & $\begin{array}{l}\text { - Gamelan, } \\
\text { - Angklung }\end{array}$ & $\begin{array}{l}\text { - } \text { Permainan Dhelikan } \\
\text { - } \text { Permainan } \\
\text { - Lempung Terigu }\end{array}$ & $\begin{array}{l}\text { Meneladani } \\
\text { sikap disiplin, } \\
\text { kejujuran dan } \\
\text { perwatakan dari } \\
\text { tokoh dalam } \\
\text { cerita. }\end{array}$ \\
\hline 2 & $\begin{array}{l}\text { Sikap } \\
\text { Kepahlawanan }\end{array}$ & 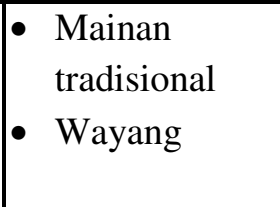 & - & $\begin{array}{l}\text { Memaknai sikap } \\
\text { kebersamaan } \\
\text { saat bermain. } \\
\text { Meneladani }\end{array}$ \\
\hline
\end{tabular}

\begin{tabular}{|l|l|l|l|l|}
\hline & & & $\begin{array}{l}\text { sikap dari tokoh } \\
\text { wayang yang } \\
\text { dijadikan media. }\end{array}$ \\
\hline 3. & $\begin{array}{l}\text { Aku dan Cita- } \\
\text { citaku }\end{array}$ & $\begin{array}{l}\text { Tugu Jogja } \\
\text { Tugu Jogja } \\
\text { Membuat kolase }\end{array}$ & $\begin{array}{l}\text { Memaknai } \\
\text { filosofis tugu } \\
\text { jogja }\end{array}$ \\
\hline
\end{tabular}


Diterbitkan oleh Lembaga Pengabdian kepada Masyarakat

Universitas Ahmad Dahlan Yogyakarta

\begin{tabular}{|l|l|l|}
$\bullet$ & dengan tema & $\begin{array}{l}\text { Meneladani } \\
\text { sayang }\end{array}$ \\
& & $\begin{array}{l}\text { sikap dari tokoh } \\
\text { wayang yang } \\
\text { digambarkan. }\end{array}$ \\
\hline
\end{tabular}

\section{Peran Profesi Kependidikan dalam Menghadapi MEA}

Dalam menghadapi Masyarakat Ekonomi ASEAN (MEA) maka harus disiapkan Sumber Daya Manusia (SDM) yang baik, terutama untuk menyiapkan kualitas siswa yang baik maka potensi guru yang perlu dikembangkan. Dalam menghadapi MEA banyak tantangan yang nantinya dihadapi bagi dunia pendidikan, sehingga sejak awal sudah harus mempersiapkan diri terutama para guru harus mempunyai kualitas dan kapabilitas yang mampu mengimplementasikan keduanya dalam lingkup regional dan nasional.

Dalam penerapannya pada tahun 2015, AEC/ MEA akan menerapkan 12 sektor prioritas yang disebut free flow of skilled labor (arus bebas tenaga kerja terampil) untuk perawatan kesehatan (health care), turisme (tourism), jasa logistik (logistic services), e-ASEAN, jasa angkutan udara (air travel transport), produk berbasis agro (agrobased products), barang-barang elektronik (electronics), perikanan (fisheries), produk berbasis karet (rubber based products), tekstil dan pakaian (textiles and apparels), otomotif (automotive), serta produk berbasis kayu (wood based products).

Pendidikan mengarahkan peserta didik pada learning to do dan learning to live together. Seorang filsuf, Confusius dalam Wesfix (2013:6-7) lebih menekankan moral daripada pengetahuan dalam sebuah pendidikan. Ia lebih memperhatikan moral dibandingkan dengan pengetahuan dan menata perilaku untuk saling menghormati antar bagian dalam masyarakat, manusia akan jadi lebih baik. Dalam situasi saling hormat-menghormati terciptalah harmoni, sehingga ajaran apapun akan diterima secara mudah.

\section{HASIL}

\section{Tabel 2.}

Hasil Integrasi Nilai-Nilai Sosiokultural pada Program Pengabdian Masyarakat dalam Pelatihan Pembuatan Bahan Ajar Berbasis Sosiokultural di SD Muhammadiyah

Gendol 7

\begin{tabular}{|c|l|c|c|c|}
\hline No & Sub Tema & $\begin{array}{c}\text { Bahan ajar } \\
\text { dengan Budaya } \\
\text { (Media) }\end{array}$ & $\begin{array}{c}\text { Bahan ajar dengan } \\
\text { (Hasil Karya) }\end{array}$ & $\begin{array}{c}\text { Bahan ajar dengan } \\
\text { Berbudaya (RPP) }\end{array}$ \\
\hline 1. & $\begin{array}{l}\text { Pengetahuan } \\
\text { tentang Bahan } \\
\text { Ajar } \\
\text { Berbasis } \\
\text { Sosiokultural }\end{array}$ & Modul & Diskusi kelompok & Meneladani nilai-nilai \\
Makalah & $\begin{array}{l}\text { sosiokultural untuk } \\
\text { menyusun bahan ajar. }\end{array}$ \\
\hline
\end{tabular}




\begin{tabular}{|c|c|c|c|c|}
\hline 2. & $\begin{array}{l}\text { Pengetahuan } \\
\text { tentang Kriteria } \\
\text { Pemilihan } \\
\text { Bahan } \\
\text { Pembelajaran. }\end{array}$ & Power point & & $\begin{array}{l}\text { Mengetahui dan } \\
\text { memahami kriteria } \\
\text { bahan } \\
\text { ajar yang relevan } \\
\text { dengan } \\
\text { materi yang } \\
\text { disampaikan. }\end{array}$ \\
\hline 3. & $\begin{array}{l}\text { Prosedur } \\
\text { Penyusunan } \\
\text { dan } \\
\text { Pengembangan } \\
\text { Bahan Ajar }\end{array}$ & $\begin{array}{l}\text { Microsoft } \\
\text { Office }\end{array}$ & $\begin{array}{l}\text { Menyusun work } \\
\text { instruction } \\
\text { pembuatan bahan } \\
\text { ajar berbasis } \\
\text { sosiokultural }\end{array}$ & $\begin{array}{l}\text { Mampu membuat dan } \\
\text { menuliskan secara } \\
\text { rinco } \\
\text { langkah-langkah } \\
\text { pembuatan bahan ajar } \\
\text { berbasis sosiokultural. }\end{array}$ \\
\hline 4. & $\begin{array}{l}\text { Profesionalism } \\
\mathrm{e} \\
\text { Guru dalam } \\
\text { MenghadapiMa } \\
\text { sya } \\
\text { rakat Ekonomi } \\
\text { ASEAN } \\
\text { (MEA) }\end{array}$ & $\begin{array}{l}\text { Power point } \\
\text { Hasil karya } \\
\text { untuk } \\
\text { pembelajaran } \\
\text { sosiokultural }\end{array}$ & $\begin{array}{l}\text { Praktik Pembuatan } \\
\text { Bahan Ajar } \\
\text { Berbasis } \\
\text { Sosiokultural }\end{array}$ & $\begin{array}{l}\text { Memahami peran guru } \\
\text { dalam era MEA. } \\
\text { Memaparkan dan } \\
\text { menjelaskan secara } \\
\text { rinci } \\
\text { peran guru dalam } \\
\text { menghadapi era MEA. }\end{array}$ \\
\hline
\end{tabular}

Berdasarkan uraian pada tabel tersebut, penulis mendapati hasil sebagai berikut:

1. Guru yang mengikuti pelatihan sebanyak 24 orang, memiliki kemampuan awal yang sama sehingga materi dapat serentak diajarkan.

2. Dari 24 orang, hanya 3 orang yang belum mahir dalam menggunakan bahan-bahan untuk membuat bahan ajar yang ada di sekelilingnya, dikarenakan baru mengenal materi sosiokultural.

3. Dari 24 orang, terbagi menjadi 4 kelompok, masing-masing sudah bisa membuat peta analisis dan konsep penyusunan bahan ajar berbasis sosiokultural. Namun, ada 1 kelompok yang memiliki kekurangan dalam presentasi dikarenakan salah persepsi dalam menangkap instruksi dari pemateri. Selebihnya, sudah mengerti meskipun masih perlu pembelajaran lebih lanjut. 

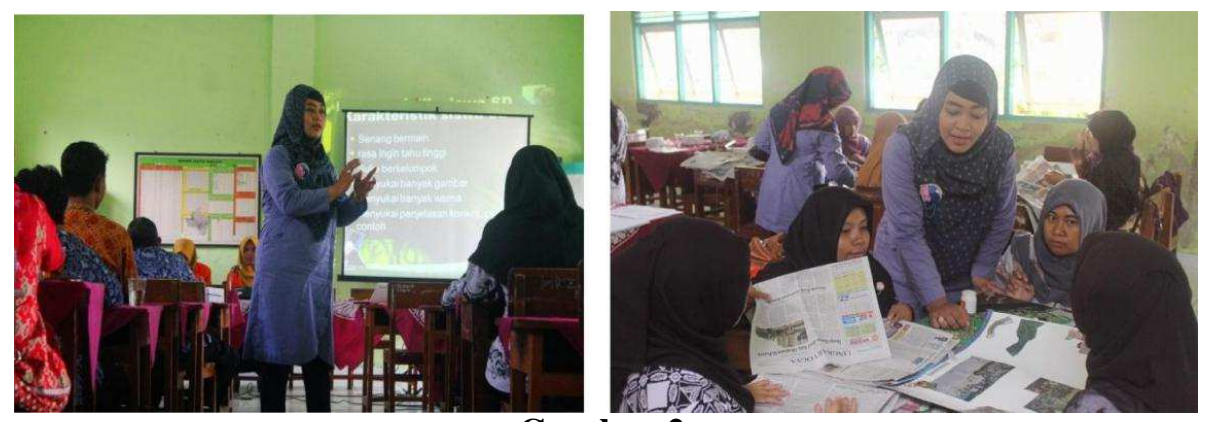

\section{Gambar 2.}

Proses Pemberian Pengarahan dan Pendampingan oleh Pemateri

(Sumber: Koleksi Pribadi, Vera Yuli Erviana, 2017)
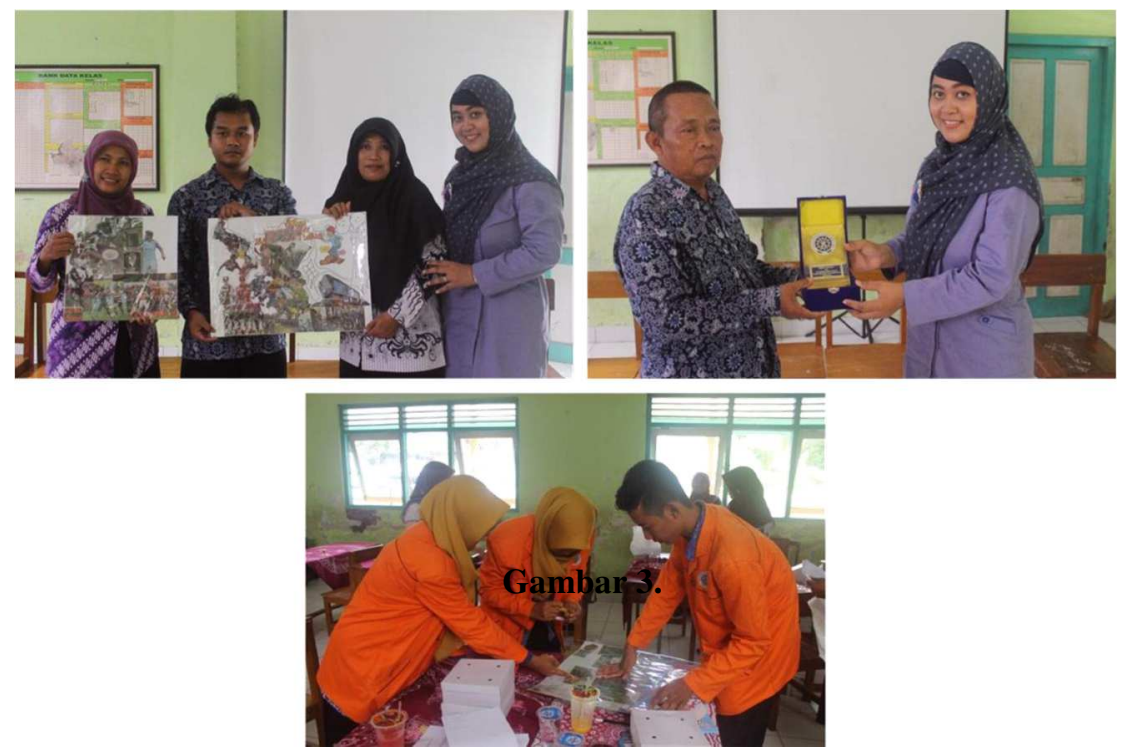

Beberapa peserta berfoto dengan hasil pembuatan bahan ajar berbasis sosiokultural (kiri atas) pemateri penyerahan kenang-kenangan kepada

Kepala Sekolah SD Muhammadiyah Gendol 7 (kanan atas), mahasiswa PGSD FKIP UAD ikut berpartisipasi (tengah bawah)

(Sumber: Koleksi Pribadi, Vera Yuli Erviana, 2017)

\section{KESIMPULAN}

Pelatihan pemanfaatan ini sangat diperlukan bagi guru sebagai salah satu cara untuk mempermudah mereka terutama dalam pembuatan bahan ajar, sehingga dapat memudahkan dalam mengajar. Guru dapat menerapkan pengetahuan sosiokultural untuk menyampaikan materi dalam proses pembelajaran. Motivasi dan keinginan yang tinggi untuk belajar akan pengetahuan baru tidak hanya dimiliki oleh generasi muda, peserta pelatihan yang sebagian sudah paruh baya memiliki semangat yang tinggi. Guru memiliki pengetahuan tentang pembuatan bahan ajar berbasis sosiokultural. 


\section{E. DAFTAR PUSTAKA}

Erviana, Vera Yuli. 2014. Pengembangan Perangkat Pembelajaran dalam Kegiatan Tematik Integratif Ada Tema Pengalamanku Berbasis Sosiokultural bagi Peserta Didik Kelas I Sekolah Dasar Negeri Serayu. Tesis. PPs UNY tidak diterbitkan.

Majid, Abdul. 2012. Perencanaan Pembelajaran Mengembangkan StandarKompetensi Guru. (Bandung: PT. Remaja Rosdakarya Offset).

Nurhidayati. 2013. Bahan Ajar (online). http://nurhidayatibj.blogspot.co.id/2013/05/bahan-ajar_8069.html (Diakses 16 September 2015

Dianhusada. 2012. Prosedur Pengembangan Bahan Ajar (online). http://dianhusadadanagueree.blogspot.co.id/p/prosedur-pengembangan-bahanajar.html (Diakses 16 September 2015)

Zulkanairni. 2009. Teknik Penyusunan Bahan Ajar (Online) https://zulkarnainidiran.wordpress.com/2009/06/28/131/ (Diakses 16 September 2015)

Jefri, Irawan. 2012 Karakteristik Bahan Ajar (Online) http://jefriirawan.blogspot.co.id/2014/10/karakteristik-bahan-ajar.html (Diakses 16 September 2015) 